\title{
High Fidelity Self-Sorting Assembling of meso-Cinchomeronimide Appended meso-meso Linked Zn(II) Diporphyrins
}

\author{
Taisuke Kamada, ${ }^{+}$Naoki Aratani, ${ }^{+}$Toshiaki Ikeda, $^{+}$Naoki Shibata, ${ }^{\ddagger}$ Yoshiki Higuchi, ${ }^{*, \neq}$

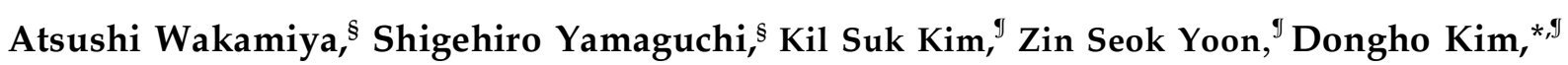 \\ and Atsuhiro Osuka ${ }^{*,+}$ \\ 'Department of Chemistry, Graduate School of Science, Kyoto University, and CREST (Core Research for Evolutional \\ Science and Technology) of Japan Science and Technology Agency, Kyoto 606-8502, Japan, ${ }^{\neq}$Graduate School of Life Science, \\ University of Hyogo, 3-2-1 Koto, Kamigori-cho, Ako-gun, Hyogo 678-1297, and RIKEN Harima Institute/SPring-8, 1-1-1 \\ Koto, Mikazuki-cho, Sayo-gun, Hyogo 679-5248, Japan, ${ }^{\circledR}$ Department of Chemistry, Graduate School of Science, Nagoya \\ University, Chikusa, Nagoya 464-8602, Japan, and ${ }^{\Phi}$ Center for Ultrafast Optical Characteristics Control and Department of \\ Chemistry, Yonsei University, Seoul 120-749, Korea
}

\section{Contents}

SI 1. GPC Chromatograms of $\left(7_{\text {out-out }}\right)_{5},\left(7_{\text {in-out }}\right)_{4}$ and $\left(7_{\text {in-in }}\right)_{3}$.

SI 2. Chiral Separation of $\left(7_{\text {in-in }}\right)_{3}$ by HPLC.

SI 3. CD Spectra of $\left(7_{\text {out-out }}\right)_{5},\left(7_{\text {in-out }}\right)_{4}$, and $\left(7_{\text {in-in }}\right)_{3}$.

SI 4. Schematic Representations of Excitonically Coupled Dipole Moments in $(R-7)_{n}$.

SI 5. Concentration Dependencies of Absorption Spectra of $\left(7_{\text {out-out }}\right)_{5},\left(7_{\text {in-out }}\right)_{4}$, and $\left(7_{\text {in-in }}\right)_{3}$.

SI 6. ${ }^{1} \mathrm{H}$ NMR Spectra of $R-7_{\text {out-out }}, R-7_{\text {in-out }}$, and $R-7_{\text {in-in }}$ in pyridine- $d_{5}$.

SI 7. Full list of the authors of ref. 16.

Table S1. Crystal Data and Structure Refinement for $(2)_{3}$.

Table S2. Crystal Data and Structure Refinement for $\left(R-7_{\text {in-in }}\right)_{3}$.

Table S3. Crystal Data and Structure Refinement for $\left(R-7_{\text {out-out }}\right)_{5}$. 


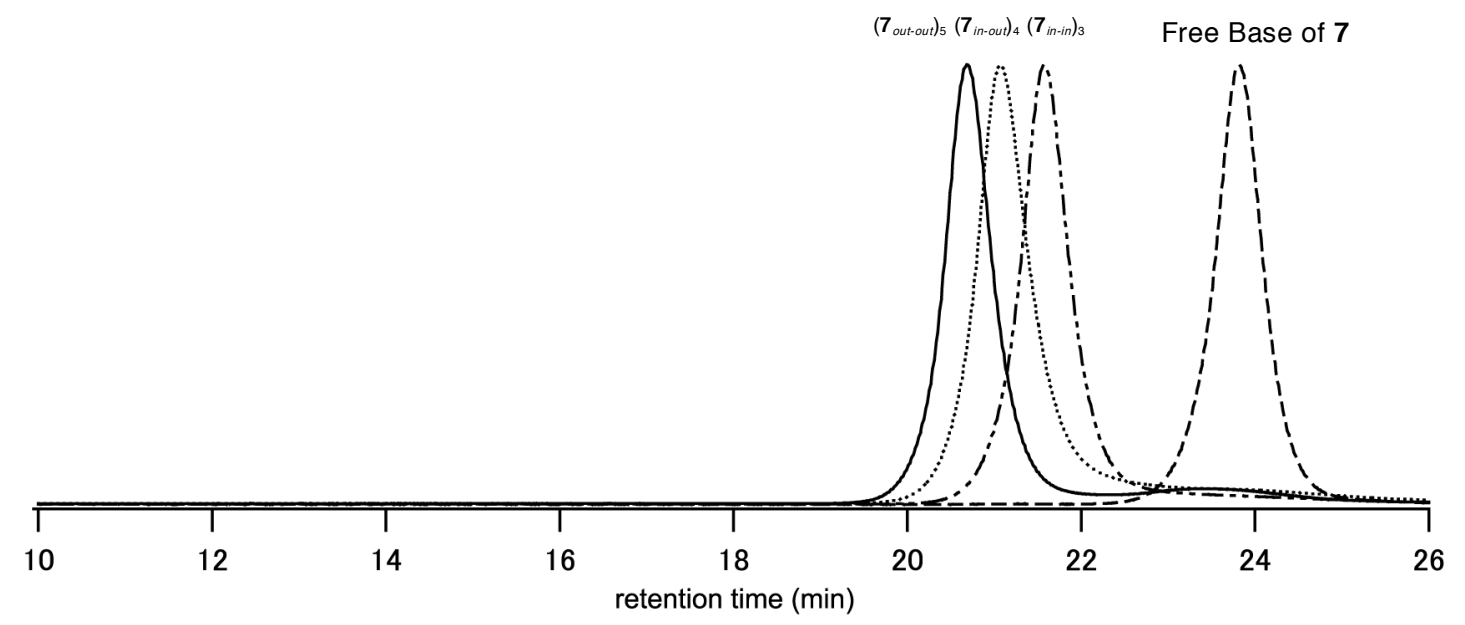

SI 1. Analytical GPC-HPLC chromatograms (2.5H-AF, $3 \mathrm{H}-\mathrm{AF}$ and $4 \mathrm{H}-\mathrm{AF}$, flow rate $=1.2$ $\mathrm{ml} / \mathrm{min}, 35^{\circ} \mathrm{C}$ ) eluted with $\mathrm{CHCl}_{3}$. 


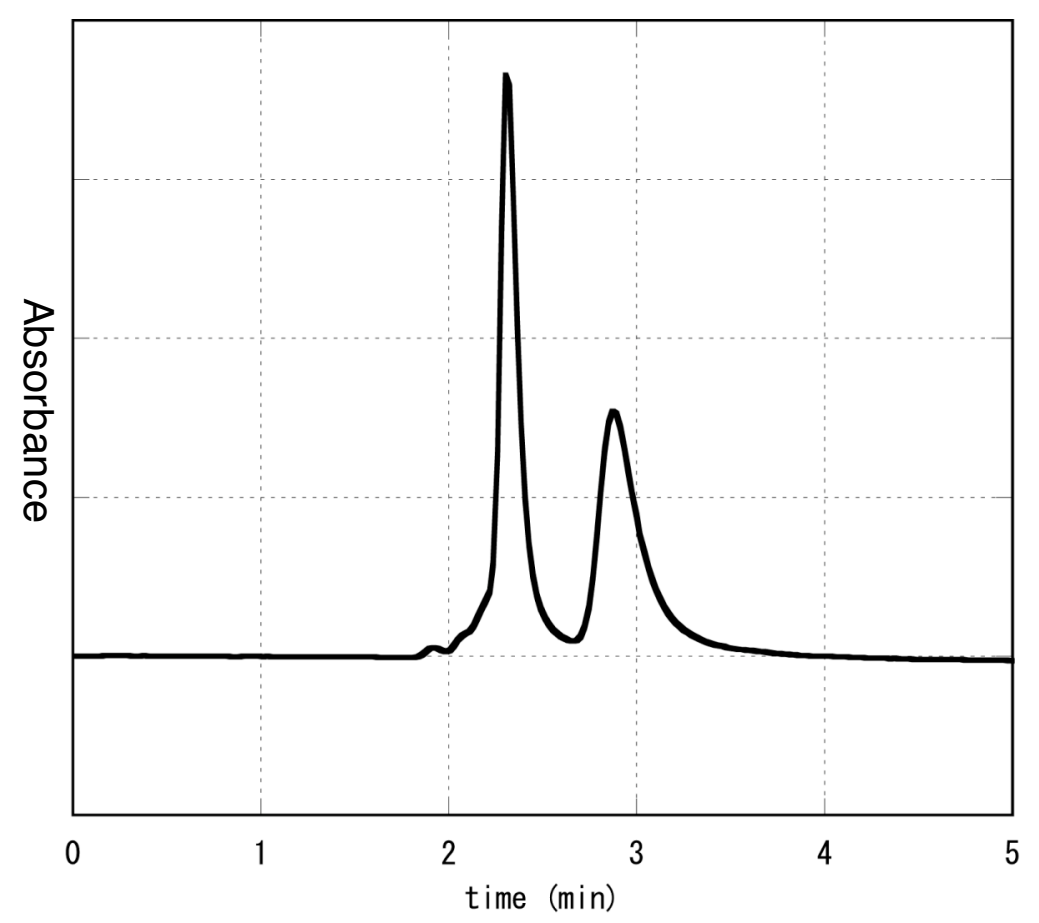

SI 2. Optical resolution of $\left(7_{\text {in-in }}\right)_{3}\left(\right.$ SUMICHIRAL OA-3100, $\mathrm{CH}_{2} \mathrm{Cl}_{2}$ :hexane $\left.=1: 2\right)$ 

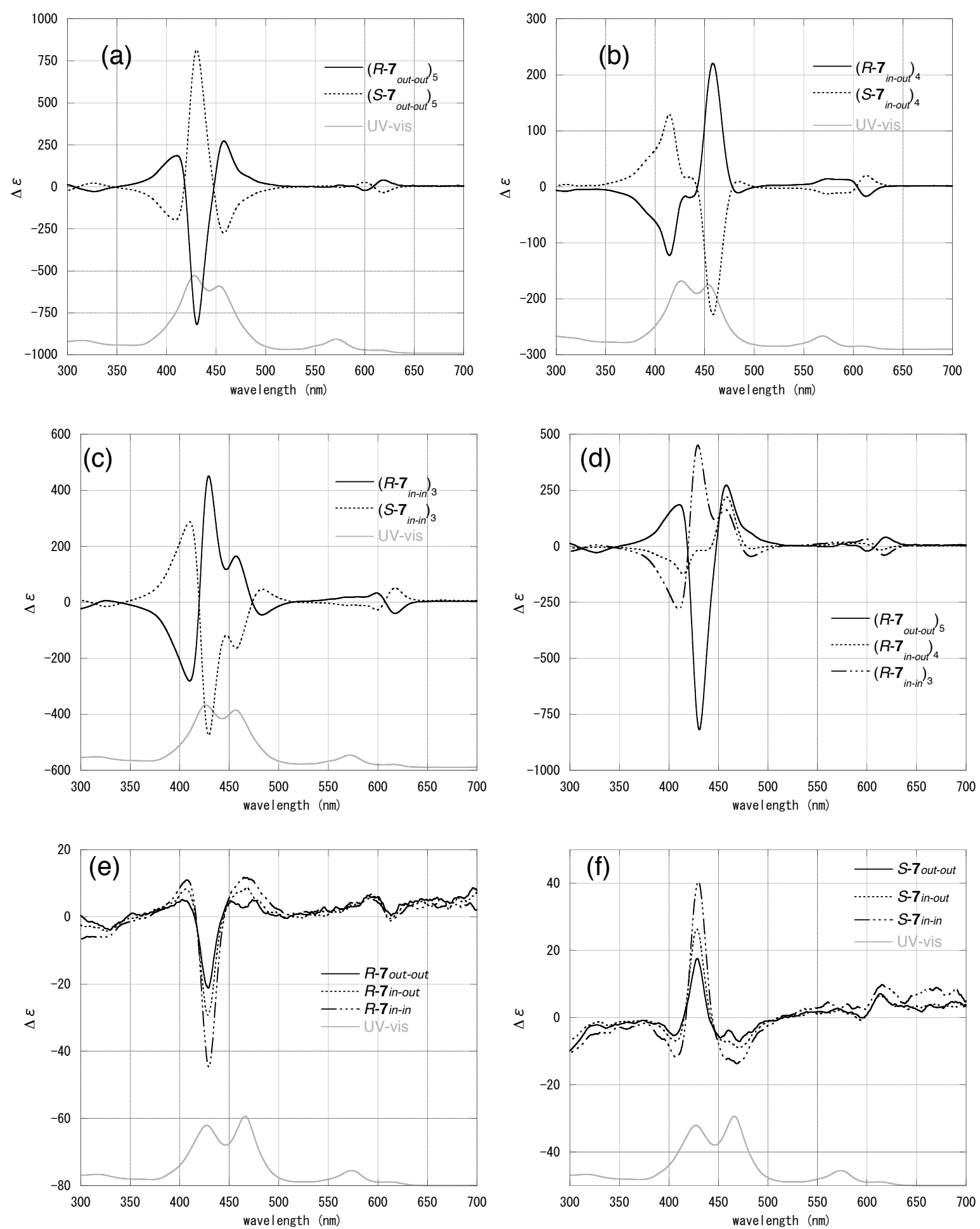

SI 3. CD and UV-vis absorption spectra of (a) $\left(7_{\text {out-out }}\right)_{5}$ in $\mathrm{CHCl}_{3}$, (b) $\left(7_{\text {in-out }}\right)_{4}$ in $\mathrm{CHCl}_{3}$, (c) $\left(7_{\text {in-in }}\right)_{3}$ in $\mathrm{CHCl}_{3}$, (d) $R-7$ in $\mathrm{CHCl}_{3}$, (e) $R-7$ in pyridine, and (f) $S-7$ in pyridine. 


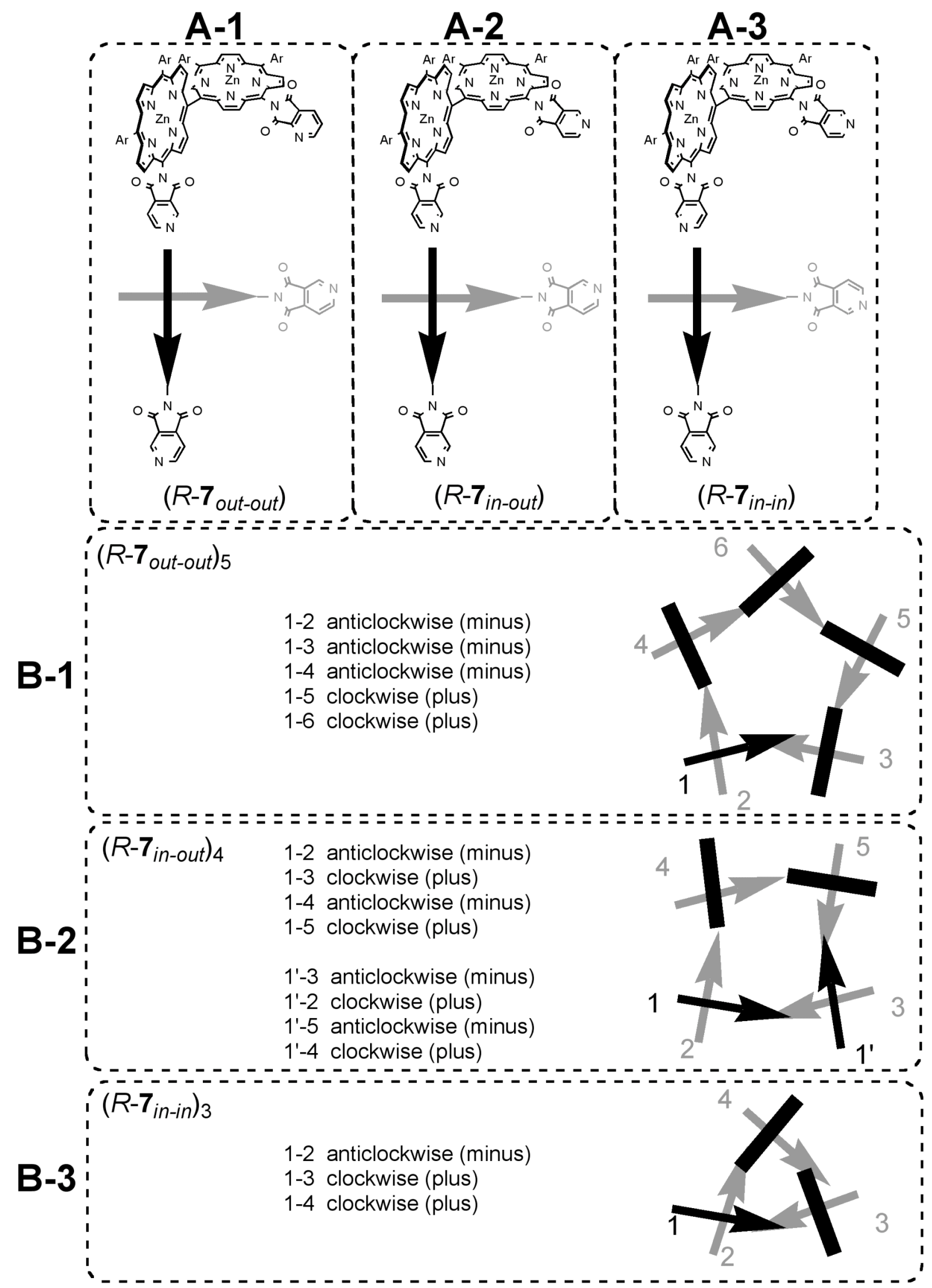

SI 4. Schematic representations of excitonically coupled dipole moments in $R-7$. 


\section{Analysis of CD spectra}

1) The Cotton effects around $430 \mathrm{~nm}$ are arising from the exciton coupling between the transition dipole moments along the short axis of meso-meso linked diporphyrin. From the negative Cotton effects at $430 \mathrm{~nm}$ of free (liberated) diporphyrins observed in pyridine (SI 3 (e)), three conformational isomers of $7\left(7_{\text {in-in }}, 7_{\text {in-out }}\right.$, and $\left.\mathbf{7}_{\text {out-out }}\right)$ have been assigned as $R$-isomers (SI $4 \mathrm{~A}$ ).

2) Figure SI 4 B-1 summarizes possible exciton interactions of the transition dipole moment 1 (solid arrow) with other dipole moments along the short molecular axis in $\left(R-7_{\text {out-out }}\right)_{5}$. Since there is no Cotton effect between dipole moments in coplanar arrangements, we do not have to consider the interaction of 1 with the dipole moments indicated by solid bars. Instead, we have to consider the interaction of 1 with the dipole moments $(2,3,4,5$, and 6$)$ represented by gray arrows. On the basis of the exciton chirality method, these interactions are divided into anticlockwise and clockwise ones (SI 4 B-1).

3) Since the exciton interactions depend on the distance between the dipole moments, the interactions of 1 with 2, 3, and 4 are larger than those with 5 and 6 . This analysis leads to the prediction that anticlockwise manner interactions are predominant in $\left(R-7_{\text {out-out }}\right)_{5}$, which is in line with the observed strong negative Cotton effect in its CD spectrum.

4) Figure SI 4 B-2 summarizes the possible exciton interactions of the transition dipole moments 1 and $1^{\prime}$ in $\left(R-7_{\text {in-out }}\right)_{4}$. Importantly, the two dipole moments 1 and $1^{\prime}$ are different and their overall interaction with other dipole moments are cancelled out, leading to only small Cotton effects around $430 \mathrm{~nm}$.

5) Figure SI 4 B-3 summarizes the possible exciton interactions of the transition dipole moments 1 and $1^{\prime}$ in $\left(R-7_{i n-i n}\right)_{3}$. In this case, we have to consider the interactions of 1 with the transition dipole moments 2, 3, and 4 . The interaction of 1 with 2 is anticlockwise with a center-to-center distance of ca. $8.3 \AA$ and the interactions of 1 with 3 and 4 are clockwise with center-to-center distances of ca. $11.4 \AA$, hence accounting for the observed positive Cotton effect around $430 \mathrm{~nm}$.

Reference: Nakanishi, K.; Berova, N. In Circular Dichroism: Pronciples and Applications; Nakanish, K.; Berova, N.; Woody, R. W., Eds.: VCH Publishers Inc.: NewYork, 1994, p 361. 
(a)

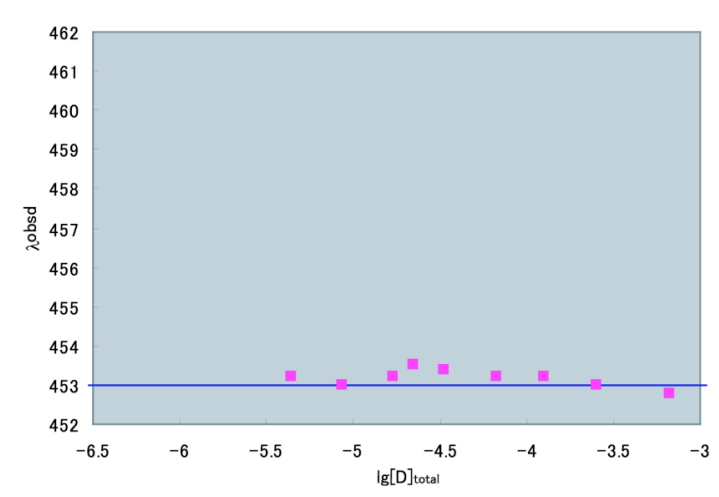

(c)

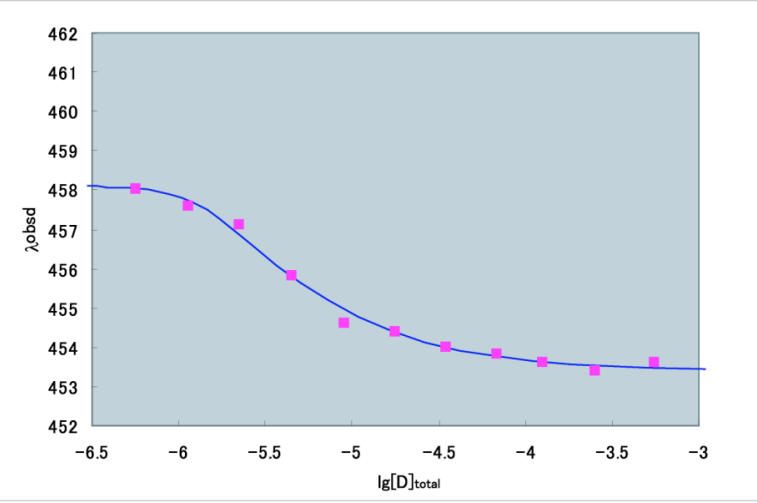

(b)

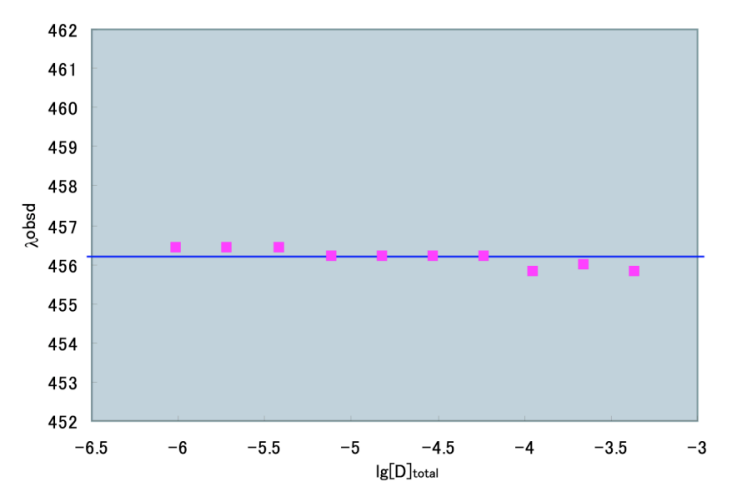

(d)

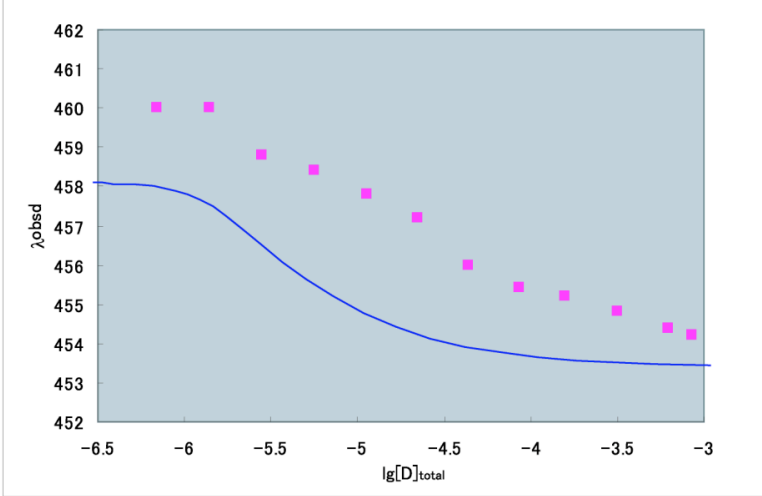

SI 5. Concentration dependencies of the absorption spectra of (a) $R-7_{\text {out-out }}$ (b) $R-7_{\text {in-in }}$ (c) $R-7_{\text {in-out }}$, and (d) racemic $7_{\text {in-out }}$ in $\mathrm{CHCl}_{3}$. Observed concentration independent features for $R-7_{\text {out-out }}$ and $R-7_{\text {in-in }}$ indicated large association constants, whereas the curve fit of the data for $R-7_{\text {in-out }}$ provided $\mathrm{K}_{\mathrm{a}}=2.0 \times 10^{16} \mathrm{M}^{-3}$. With racemic $7_{\text {in-out }}$ precursor, the observed plots deviated significantly from those of $R-7_{\text {in-out }}$. 

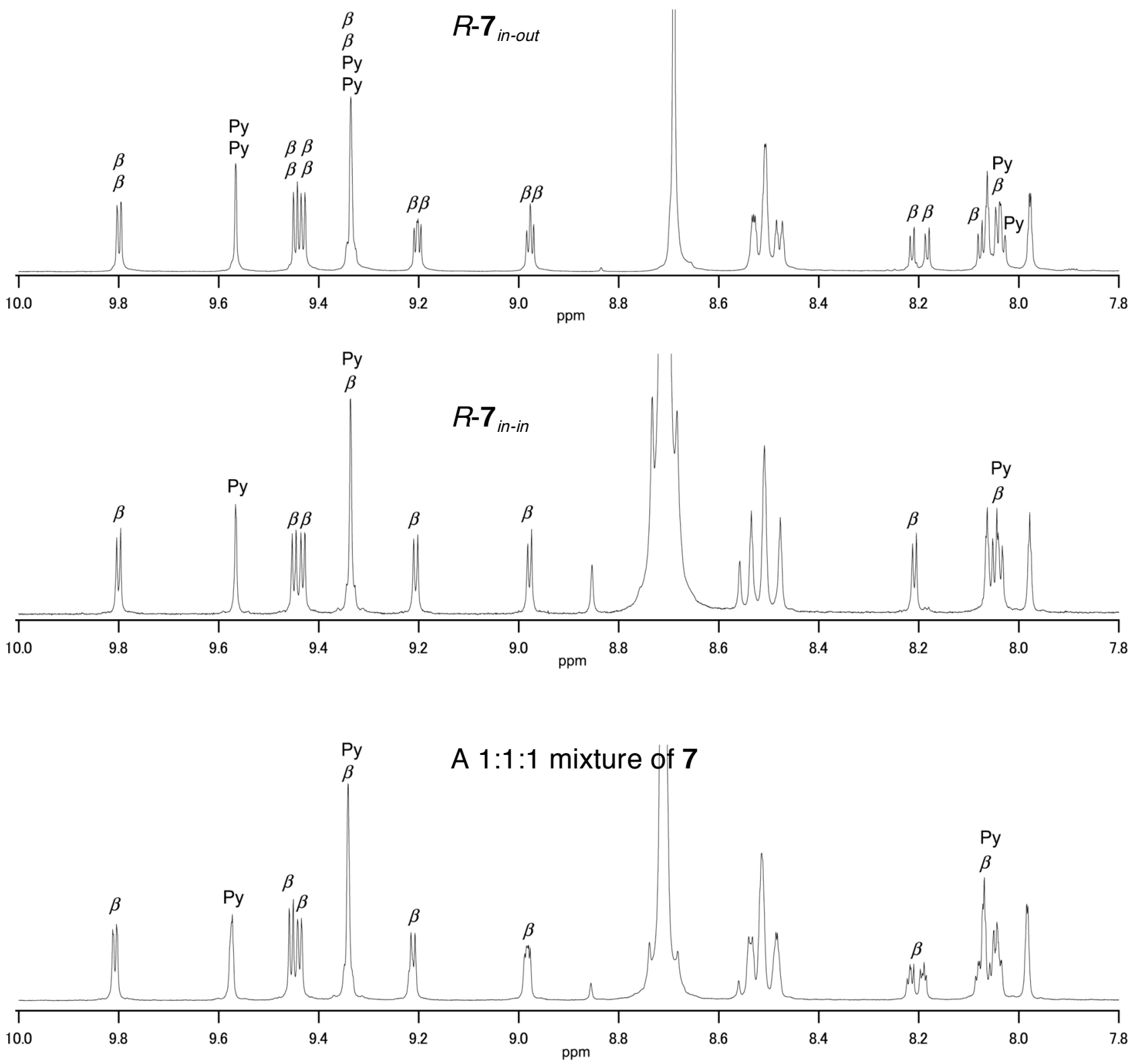

SI 6. ${ }^{1} \mathrm{H}$ NMR spectra of $R-7_{\text {out-out }}, R-7_{\text {in-out }}, R-7_{\text {in-in }}$ and a mixture of $\mathbf{7}$ in pyridine- $d_{5}$. These spectra are similar one another but there are clear differences in the range of 7.9-9.2 ppm, indicating that three different conformers are present in respective samples. 


\section{SI7. Full list of the authors in ref. 16}

Frisch, M. J.; Trucks, G. W.; Schlegel, H. B.; Scuseria, G. E.; Robb, M. A.; Cheeseman, J. R.; Montgomery, Jr. J. A.; Vreven, T.; Kudin, K. N.; Burant, J. C.; Millam, J. M.; Iyengar, S. S.; Tomasi, J.; Barone, V.; Mennucci, B.; Cossi, M.; Scalmani, G.; Rega, N.; Petersson, G. A.; Nakatsuji, H.; Hada, M.; Ehara, M.; Toyota, K.; Fukuda, R.; Hasegawa, J.; Ishida, M.; Nakajima, T.; Honda, Y.; Kitao, O.; Nakai, H.; Klene, M.; Li, X.; Knox, J. E.; Hratchian, H. P.; Cross, J. B.; Adamo, C.; Jaramillo, J.; Gomperts, R.; Stratmann, R. E.; Yazyev, O.; Austin, A. J.; Cammi, R.; Pomelli, C.; Ochterski, J. W.; Ayala, P. Y.; Morokuma, K.; Voth, G. A.; Salvador, P.; Dannenberg, J. J.; Zakrzewski, V. G.; Dapprich, S.; Daniels, A. D.; Strain, M. C.; Farkas, O.; Malick, D. K.; Rabuck, A. D.; Raghavachari, K.; Foresman, J. B.; Ortiz, J. V.; Cui, Q.; Baboul, A. G.; Clifford, S.; Cioslowski, J.; Stefanov, B. B.; Liu, G.; Liashenko, A.; Piskorz, P.; Komaromi, I.; Martin, R. L.; Fox, D. J.; Keith, T.; Al-Laham, M. A.; Peng, C. Y.; Nanayakkara, A.; Challacombe, M.; Gill, P. M. W.; Johnson, B.; Chen, W.; Wong, M. W.; Gonzalez, C.; Pople, J. A. Gaussian 03, Revision B.05; Gaussian, Inc.: Pittsburgh, PA, 2003. 
Table S1. Crystal data and structure refinement for $(2)_{3}$.

Formula

Formula weight

Temperature

Wavelength

Crystal system

Space group

Unit cell dimensions

Volume

$\mathrm{Z}$

Density (calculated)

Absorption coefficient

$\mathrm{F}(000)$

Crystal size

Theta range for data collection

Reflections collected

Independent reflections

Absorption correction

Max. and min. transmission

Refinement method

Data / restraints / parameters

Goodness-of-fit on $\mathrm{F}^{2}$

Final $\mathrm{R}$ indices [I>2sigma(I)]

$\mathrm{R}$ indices (all data)

Largest diff. peak and hole

CCDC reference number
C376H324N47O17Zn6

6149.04

120(2) K

$0.71073 \AA$

Rhombohedral

R-3

$a=22.8553(7) \AA \alpha=90^{\circ}$

$b=22.8553(7) \AA \beta=90^{\circ}$

$c=60.016(4) \AA \quad \gamma=120^{\circ}$

27150(2) $\AA^{3}$

3

$1.128 \mathrm{Mg} / \mathrm{m}^{3}$

$0.454 \mathrm{~mm}^{-1}$

9651

$0.40 \times 0.30 \times 0.10 \mathrm{~mm}^{3}$

1.08 to $28.32^{\circ}$

52174

$13839[\mathrm{R}(\mathrm{int})=0.0953]$

Empirical

0.9560 and 0.8391

Full-matrix least-squares on $\mathrm{F}^{2}$

13839 / 15 / 646

0.969

$R_{1}=0.0992,{ }_{w} R_{2}=0.2875$

$R_{1}=0.2003,{ }_{w} R_{2}=0.3300$

1.093 and -0.400 e. $\AA^{-3}$

281543 

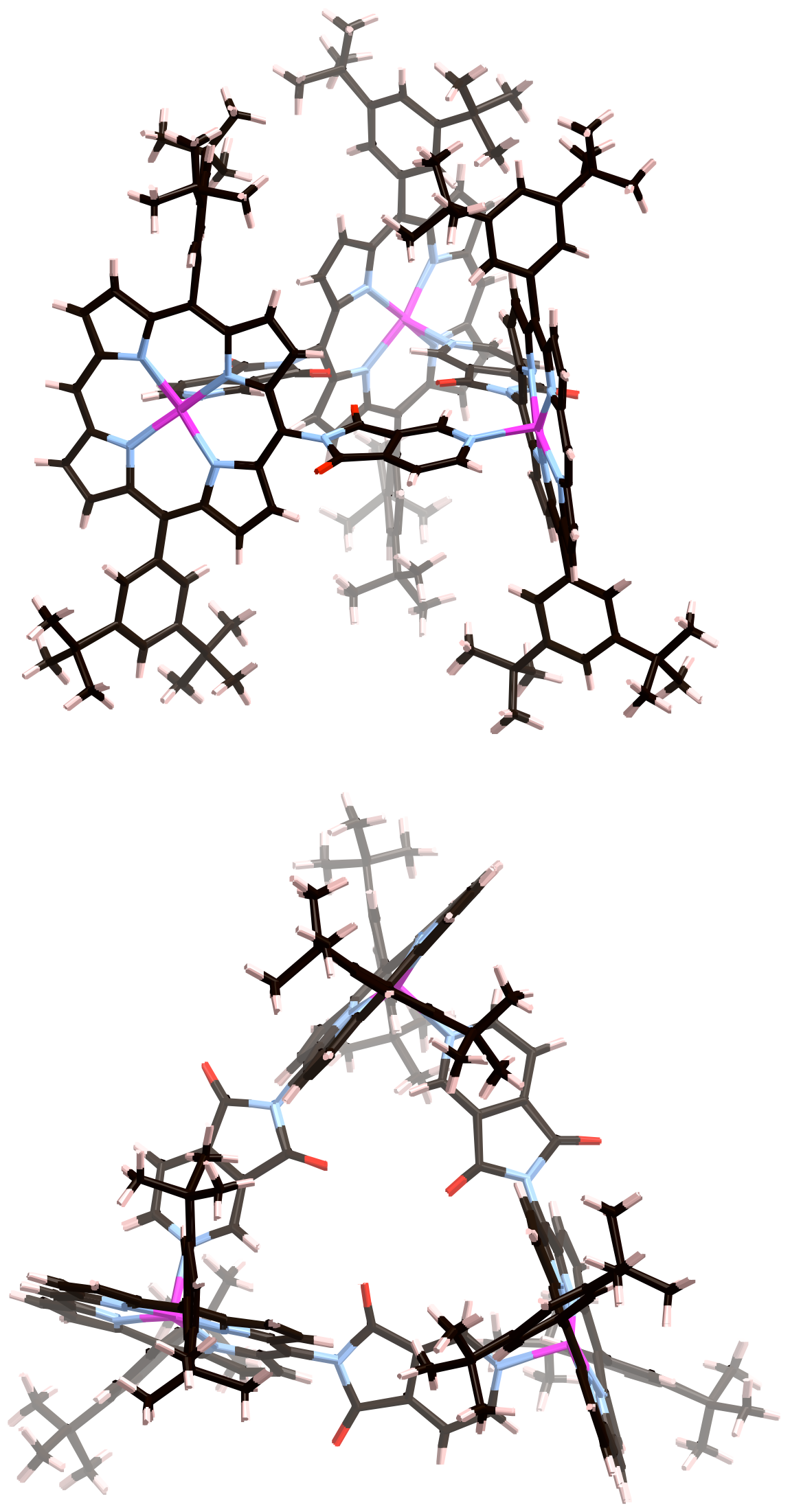
Table S2. Crystal data and structure refinement for $\left(R-7_{i n-i n}\right)_{3}$.

Formula

Formula weight

Temperature

Wavelength

Crystal system

Space group

Unit cell dimensions

Volume

Z

Density (calculated)

Absorption coefficient

$\mathrm{F}(000)$

Crystal size

Theta range for data collection

Reflections collected

Independent reflections

Absorption correction

Refinement method

Goodness-of-fit on $\mathrm{F}^{2}$

Final $\mathrm{R}$ indices $[I>2 \operatorname{sigma}(I)]$

$\mathrm{R}$ indices (all data)

CCDC reference number
C740N82O69Zn12

13019.22

$93 \mathrm{~K}$

$0.71073 \AA$

Monoclinic

$\mathrm{P} 2_{1}$

$a=29.11(3) \AA \quad \alpha=90^{\circ}$

$b=36.06(4) \AA \quad \beta=99.48(5)^{\circ}$

$\mathcal{c}=44.22(4) \AA \quad \gamma=90^{\circ}$

45778(79) $\AA^{3}$

2

$0.945 \mathrm{Mg} / \mathrm{m}^{3}$

$0.364 \mathrm{~mm}^{-1}$

14008

$0.20 \times 0.20 \times 0.20 \mathrm{~mm}^{3}$

3.40 to $17.22^{\circ}$

24565

$41116[\mathrm{R}(\mathrm{int})=0.3143]$

Empirical

Full-matrix least-squares on F2

1.970

$R_{1}=0.1878,{ }_{w} R_{2}=0.3981$

$R_{1}=0.2324,{ }_{w} R_{2}=0.4381$

281545 

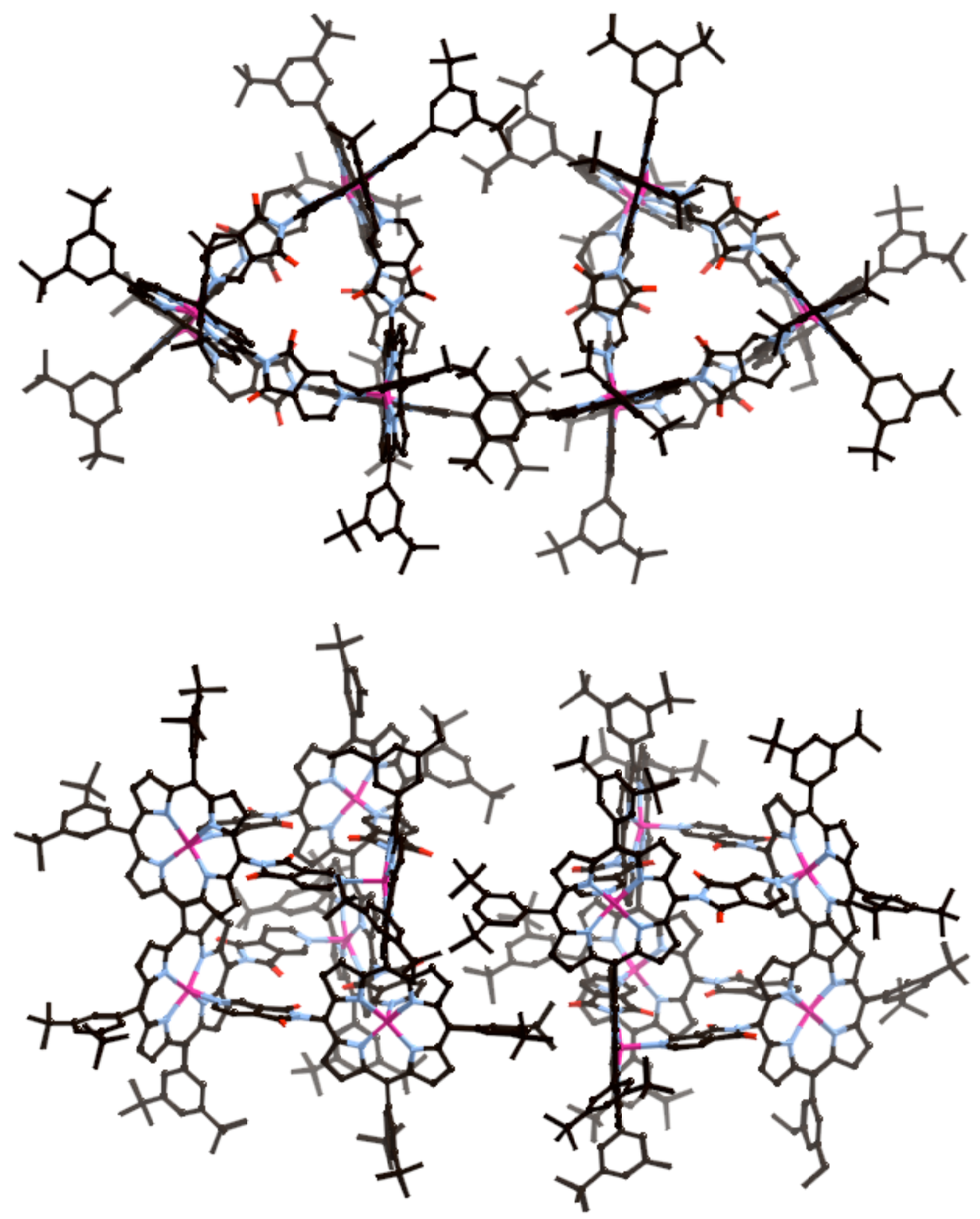
Table S3. Crystal data and structure refinement for $\left(R-7_{\text {out-out }}\right)_{5}$.

Formula

Formula weight

Temperature

Wavelength

Crystal system

Space group

Unit cell dimensions

Volume

Z

Density (calculated)

Absorption coefficient

$\mathrm{F}(000)$

Crystal size

Theta range for data collection

Reflections collected

Independent reflections

Absorption correction

Refinement method

Goodness-of-fit on $\mathrm{F}^{2}$

Final $\mathrm{R}$ indices $[I>2 \operatorname{sigma}(I)]$

$\mathrm{R}$ indices (all data)

CCDC reference number
C522 H722 N60 O20 Zn10

8811.30

293(2) K

$0.71073 \AA$

Monoclinic

$\mathrm{P} 2_{1}$

$a=29.95(3) \AA \quad \alpha=90^{\circ}$

$b=54.46(5) \AA \quad \beta=111.06(5)^{\circ}$

$c=30.26(3) \AA \quad \gamma=90^{\circ}$

46060(8) $\AA^{3}$

2

$0.635 \mathrm{Mg} / \mathrm{m}^{3}$

$0.290 \mathrm{~mm}^{-1}$

9468

$0.20 \times 0.20 \times 0.20 \mathrm{~mm}^{3}$

1.72 to $18.41^{\circ}$

56692

$44571[\mathrm{R}(\mathrm{int})=0.3143]$

Empirical

Full-matrix least-squares on $\mathrm{F}^{2}$

2.415

$R_{1}=0.1147,{ }_{w} R_{2}=0.3123$

$R_{1}=0.1277,{ }_{\mathrm{w}} R_{2}=0.3186$

281544 

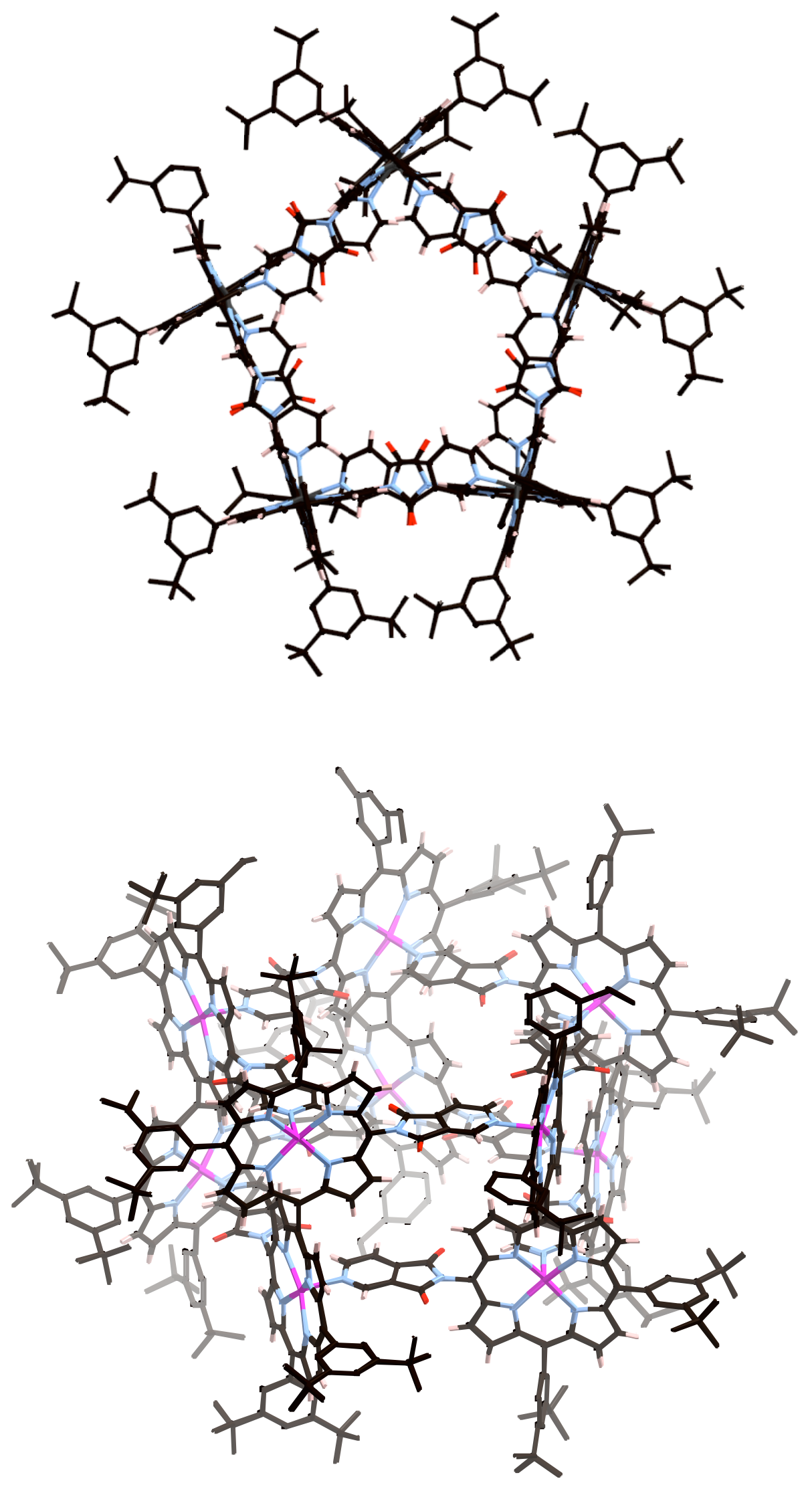